\title{
ОПТИМИЗАЦИЯ СИНТЕЗА ФАРМАЦЕВТИЧЕСКОЙ СУБСТАНЦИИ О-БЕНЗОИЛАМИНОБЕНЗОЙНОЙ КИСЛОТЫ, ОБЛАДАЮЩЕЙ АНКСИОЛИТИЧЕСКОЙ АКТИВНОСТЬЮ
}

\author{
Б.В. Боровский, Н.О. Коваль \\ Кафедра неорганической, физической и коллоидной химии, \\ Пятигорского медико-фармацевтического института - филиала ФГБОУ ВО ВолгГМУ \\ Минздрава России, 357532, Россия, г. Пятигорск, пр. Калинина, д. 11
}

DOI: 10.19163/MedChemRussia2021-2021-49Ｅ-mail: b.v.borovskiy@pmedpharm.ru

Поиск, создание и разработка экономически выгодных и экологически безопасных методов получения новых анксиолитических препаратов взамен лекарственных средств, утративших эффективность или обладающих опасными побочными свойствами, является необходимым условием развития современной медицинской и фармацевтической химии. Среди производных амидов антраниловой кислоты, обнаружено немало соединений, обладающих ценными фармакологическими свойствами и низкой токсичностью. К ним относятся производные амиды о-бензоиламинобензойной кислоты, проявляющие противовоспалительную, актопротекторную, антигипоксическую активностью и влияющие на ЦНС. Оптимизация условий синтеза биологически активных амидов о-бензоиламинобензойной кислоты, с целью наработки активной фармакологической субстанции для дальнейших фармакологических исследований является актуальной задачей. Синтез амидов о-бензоиламинобензойной кислоты взаимодействием 2-фенилбензоксазинона-4 с ароматическими аминами сопровождается конкурентной реакцией образования хиназолинонов-4, поэтому разработка метода более селективного контроля прохождения реакции перспективно для дальнейшего получения АФС.

Нами был оптимизирован многостадийный метод синтеза нового высокоэффективного и малотоксичного вещества, относящегося к ряду производных амидов о-бензоиламинобензойной кислоты и обладающего анксиолитическим действием. В данной работе нами разработан лабораторный регламент получения целевого вещества, подразумевающий технологическую простоту, экономическую выгоду и экологическую безопасность [1].

\section{Литература}

[1] Патент РФ на изобретение № 2643356 МПКП. Новое N-арилсульфамидное производное о-бензоиламинобензойной кислоты, обладающее анксиолитической, актропротекторной и антидепрессивной активностью / Оганесян Э.Т., Кодониди И.П., Манвелян Э.А., Сочнев В.С., Сыса В.Ю., Манвелян М.М. - № 2016124996; заявл. 22.06.2016 опубл. 01.02.2018. 